\title{
PEMBELAJARAN MATEMATIKA REALISTIK (PMR) PADA MATERI LUAS DI KELAS IV MI
}

\author{
Oleh: Elda Herlina*
}

\begin{abstract}
This research was aimed at figuring out whether there was influence of learning mathematics using realistic approach upon students' achievement on mathematics, especially upon width, and whether there was influence of students' attitudes upon the learning of mathematics. The data of the research were analyzed by employing descriptive statistic analysis. The finding showed that students responded positively toward realistic mathematic learning and realistic mathematic learning was effective in activating students. It was concluded that students who followed realistic mathematic learning showed better learning achievement than those of conventional one upon the topic of width.
\end{abstract}

Kata Kunci: Pembelajaran, Matematika, Realistik, Luas

\section{PENDAHULUAN}

I su tentang rendahnya mutu pendidikan matematika siswa senantiasa menjadi topik perbincangan yang hangat. Bahkan Matematika termasuk mata pelajaran yang kurang disenangi dan dianggap sulit oleh siswa dan orang tua. Padahal matematika mempunyai peranan yang sangat penting dalam kehidupan sehari-hari, sehingga matematika disebut sebagai ratunya ilmu.

Masalah ini tidak hanya dialami oleh siswa-siswa di Indonesia tetapi juga dialami oleh siswa di berbagai Negara. Di Amerika, misalnya (Brunning, 2005: 319) menyatakan bahwa banyak siswa yang kurang memahami tentang matematika yang mereka kerjakan. Banyak diantara siswa yang dapat menyelesaikan soal matematika tetapi sedikit yang memahami maknanya.

Hal ini bisa juga disebabkan oleh cara guru menyampaikan materi pelajaran yang sulit dipahami oleh siswa. Berkaitan dengan cara penyampaian materi pelajaran oleh guru, ada bermacam-macam pendekatan pembelajaran yang bisa digunakan agar materi dapat dipahami oleh siswa dengan baik. Faktor pendekatan pembelajaran adalah faktor yang sangat essensial sebab di dalam pendekatan terdapat perencanaan dan pelaksanaan pembelajaran yang akan dilaksanakan guru. Walaupun setiap guru mempunyai pendekatan sendiri dalam mengajar yang didapat dari pengalamannya, namun menurut pengamatan penulis masih banyak guru yang memakai pendekatan dengan metode klasikal formal (searah) sehingga guru menjadi penguasa kelas yang mengakibatkan siswa pasif dalam pembelajaran. Untuk mengatasi hal tersebut guru harus mengusahakan agar siswa merasa tertarik dalam belajar matematika. Siswa akan tertarik belajar matematika jika dalam pembelajaran tersebut diusahakan agar siswa berada dalam dunianya. Saat pembelajaran berlangsung dan secara berangsur-angsur siswa digiring ke dunia matematika, de-

* Penulis adalah Staf Pengajar dalam Mata Kuliah Matematika STAIN Batusangkar 
ngan harapan ketegangan anak dalam mengikuti pembelajaran dikurangi bahkan dihilangkan.

Peneliti telah melakukan pengamatan selama bulan Januari 2003 di MIN Darul Ulum Jombang tentang pelaksanaan pembelajaran matematika. Berdasarkan pengamatan sementara ditemukan beberapa fenomena, diantaranya: pembelajaran dimulai dari guru menyampaikan materi, memberikan contoh soal, dan cara penyelesaiannya, penurunan rumus dilakukan sendiri oleh guru, sementara siswa diberitahu apa yang harus dikerjakan dan bagaimana menyimpulkannya. Siswa hanya mendengarkan dan mengikuti cara guru menyelesaikan soal setelah menyampaikan materi. Kelas didominasi oleh guru, sehingga pembelajaran matematika kurang bermakna bagi siswa. Agar pembelajaran lebih bermakna maka dalam pembelajaran matematika di kelas lebih ditekankan pada keterkaitan konsep-konsep matematika dengan pengalaman siswa seharihari. Oleh karena itu diperlukan suatu pendekatan dalam pembelajaran matematika yang berorientasi pada masalah dalam kehidupan sehari-hari, demikian sehingga siswa dapat menerapkan matematika dalam kehidupan sehari-hari. Pendekatan tersebut adalah Realistic Mathematics Education (RME) yang di Indonesia lebih dikenal dengan Pembelajaran Matematika Realistik (PMR).

Pada pembelajaran geometri khususnya kondisi ini lebih serius. Pada umumnya siswa tidak mengetahui untuk apa mereka belajar konsep-konsep geometri. Begitu juga menurut (Marpaung, 2000:7) ditemukan sebagian besar guru di Sekolah Dasar kurang menguasai materi, dengan akibat mereka salah mengajarkannya kepada siswa. Hal ini disebabkan karena semua yang dipelajari siswa terasa jauh dari kehidupan seharihari. Akibatnya banyak diantara siswa yang berpendapat bahwa geometri merupakan materi yang paling sulit.

Berdasarkan uraian di atas, penulis memilih pembelajaran matematika realistik sebagai suatu pendekatan pada pembelajaran materi luas di kelas IV MI. Untuk melihat kenyataan di lapangan mengenai pembelajaran matematika Realistik, maka perlu dirumuskan masalah sebagai berikut: (1) Apakah pembelajaran matematika Realistik efektif untuk mengajarkan materi luas? (2) Apakah hasil belajar siswa yang mengikuti pembelajaran matematika realistik lebih baik dibandingkan hasil belajar siswa yang mengikuti pembelajaran konvensional pada materi luas?

\section{KAJIAN TEORITIS}

\section{Pendekatan dalam Pembelajaran Matematika}

Soedjadi (2001:102) mendefinisikan pendekatan pembelajaran sebagai proses penyampaian atau penyajian topik matematika tertentu agar mempermudah siswa memahaminya. Sedangkan pada tulisan ini yang dimaksud dengan pendekatan pembelajaran adalah suatu jalan, cara, atau kebijaksanaan yang dilakukan guru dan siswa sehingga dapat mempermudah siswa dalam memahami materi yang dipelajarinya.

Selanjutnya Treffers (1999:32) membedakan 4 pendekatan dalam pendidikan matematika. Keempat pendekatan tersebut adalah: mekanistik, empiristik, strukturalistik dan realistik. Perbedaan keempat pendekatan tersebut dilihat sejauh mana mereka memuat atau menggunakan kedua komponen matematisasi dalam pendidikan matematika. Kedua komponen itu adalah matematisasi horizontal dan matematisasi vertikal. Matematisasi horizontal berkaitan dengan pengetahuan yang telah dimiliki oleh siswa sebelumnya bersama dengan in- 
tuisi mereka sebagai alat untuk menyelesaikan masalah kontekstual. Sedangkan matematisasi vertikal berkaitan dengan proses pengorganisasian kembali pengetahuan yang diperoleh dalam simbol-simbol matematika yang lebih abstrak. Lebih lanjut Freudenthal (1991) menyatakan bahwa matematisasi horizontal bergerak dari dunia nyata ke dunia simbol sedangkan matematisasi vertikal bergerak dari dunia simbol ke dunia simbol yang lebih abstrak. Berikut ini contoh matematisasi horizontal dan matematisasi vertikal pada topik penjumlahan. Siswa diminta untuk menempatkan 12 buah permen pada dua piring sesuai dengan caranya sendiri. Dalam hal ini diharapkan jawaban yang beraneka ragam dari siswa sekaligus siswa dapat menghitung banyaknya permen yang diletakkan pada setiap piring. Kegiatan ini tergolong pada matematisasi horizontal. Selanjutnya untuk menuju ke bentuk yang lebih formal, misalnya menemukan sifat komutatif, dan assosiatif terhadap penjumlahan dapat dilakukan dengan mengembangkan pertanyaan sesuai dengan konsep yang diharapkan, hal ini merupakan kegiatan matematisasi. (Soedjadi, 2001) menggambarkan kegiatan

\section{Matematisasi horizontal}
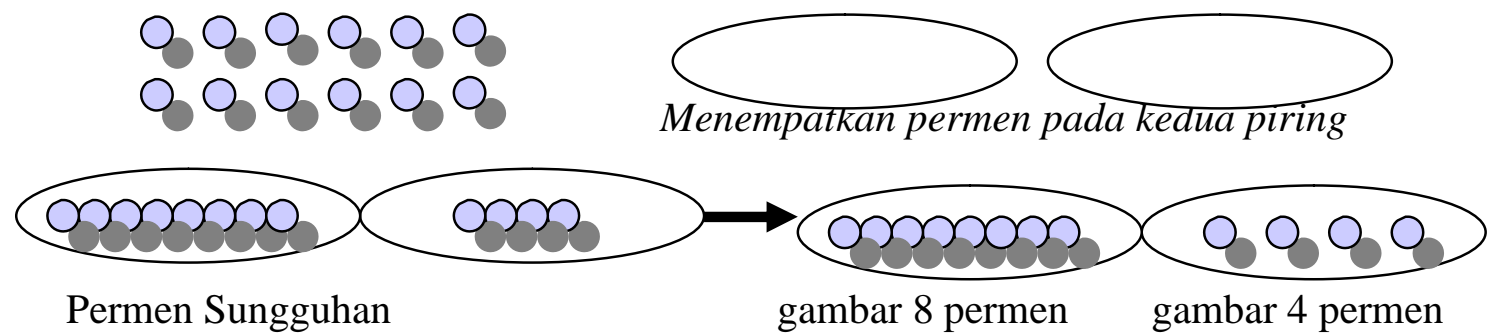

Gambar 2.1 Matematisasi Horizontal

Matematisasi vertikal

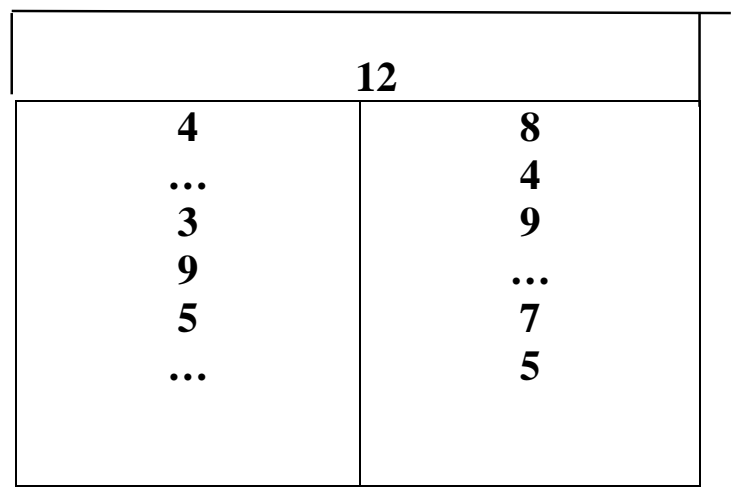

Jadi $4+8=8+4$

$3+9=9+3$

$5+7=7+5$

Bentuk matematika formal dari konsep di atas adalah $: a+b=b+a$ ( komutatif) dengan mengubah permintaan, seperti berikut ini:

1. Permen yang akan ditempatkan ke dalam piring menjadi 12 , dan sebagainya.

2. Jika piringnya ditambah menjadi tiga, ini mengarah ke sifat assosiatif

3. Jika permen di setiap piring sama banyak, ini mengarah ke pembagian.

Langkah-langkah belajar tersebut digolongkan kepada "learning trajectory atau lintasan belajar". Sehubungan dengan proses matematisasi yang diadaptasi dari (Gravemeijer, 1994) dapat digambarkan sebagai berikut: 


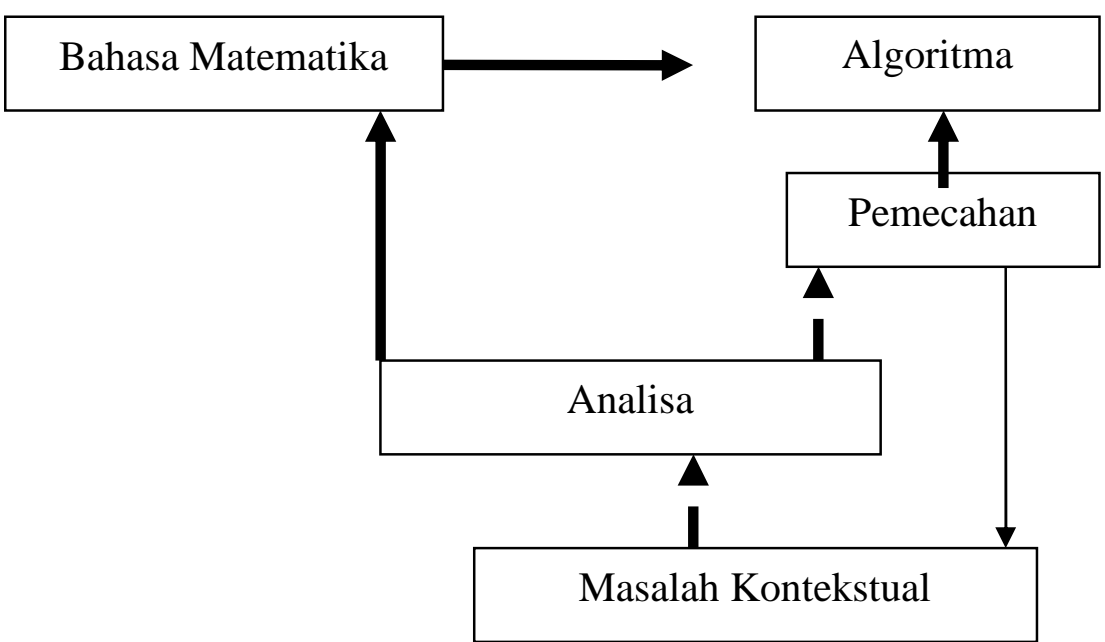

Gambar 2.2: matematisasi horizontal ( $\longrightarrow$ ) matematisasi vertikal ( $\longrightarrow$ )

Pengaplikasian kembali $(\longrightarrow)$

\section{Pembelajaran Matematika Realistik}

Salah satu karakteristik matematika adalah mempunyai objek yang bersifat abstrak. Sifat abstrak ini menyebabkan banyak siswa mengalami kesulitan dalam matematika. Prestasi matematika siswa baik secara nasional maupun internasional belum menggembirakan. Third International Mathematics and Science Study (TIMSS) melaporkan bahwa rata-rata skor matematika siswa tingkat 8 (tingkat II SLTP) Indonesia jauh di bawah rata-rata skor matematika siswa internasional dan berada pada ranking 34 dari 38 negara (TIMSS, 2003). Rendahnya prestasi matematika siswa disebabkan oleh faktor siswa yaitu mengalami masalah secara komprehensif atau secara parsial dalam matematika. Selain itu, belajar matematika siswa belum bermakna, sehingga pengertian siswa tentang konsep sangat lemah.

(Jenning dan Dunne, 1999) mengatakan bahwa, kebanyakan siswa mengalami kesulitan dalam mengaplikasikan matematika ke dalam situasi kehidupan real. Hal lain yang menyebabkan sulitnya matematika bagi siswa adalah karena pembelajaran matematika kurang bermakna. Guru dalam pembelajarannya di kelas tidak mengaitkan dengan skema yang telah dimiliki oleh siswa dan siswa kurang diberikan kesempatan untuk menemukan kembali dan mengkonstruksi sendiri ide-ide matematika. Mengaitkan pengalaman kehidupan nyata anak dengan ide-ide matematika dalam pembelajaran di kelas penting dilakukan agar pembelajaran bermakna (Menurut Van de HenvelPanhuizen (2000), bila anak belajar matematika terpisah dari pengalaman mereka sehari-hari maka anak akan cepat lupa dan tidak dapat mengaplikasikan matematika .

Berdasarkan pendapat di atas, pembelajaran matematika di kelas ditekankan pada keterkaitan antara konsep-konsep matematika dengan pengalaman anak sehari-hari. Selain itu, perlu menerapkan kembali konsep matematika yang telah dimiliki anak pada kehidupan sehari-hari atau pada bidang lain sangat penting dilakukan. Salah satu pembelajaran matematika yang berorientasi pada matematisasi pengalaman seharihari (mathematize of everyday experience) dan menerapkan matematika dalam kehidupan sehari-hari adalah pembe- 
lajaran Matematika Realistik (MR). Pembelajaran MR pertama kali dikembangkan dan dilaksanakan di Belanda dan dipandang sangat berhasil untuk mengembangkan pengertian siswa. Sedangkan (Soedjadi, 2001:2) menyatakan bahwa Pembelajaran Matematika Realistik (PMR) pada dasarnya adalah pemanfaatan realitas dan lingkungan yang dipahami siswa untuk memperlancar proses pembelajaran matematika sehingga mencapai tujuan pembelajaran matematika secara lebih baik dari masa lalu.

Dalam pandangan PMR proses pengembangan konsep-konsep atau gagasan matematika bermula dari dunia nyata. Dunia nyata ini tidak berarti secara fisik dan kasat mata, namun juga termasuk hal yang dapat dibayangkan oleh siswa. Jadi PMR menggunakan situasi nyata sebagai titik tolak belajar matematika.

Ide utama pembelajaran matematika realistik adalah bahwa siswa harus diberikan kesempatan untuk menemukan kembali konsep dan prinsip matematika dengan bimbingan orang dewasa (Gravemeijer, 1999:15). Usaha untuk menemukan kembali konsep dan prinsip matematika dapat dilakukan dengan penjelajahan situasi nyata dan permasalahan dunia nyata. (De Lange, 1999) menggambarkan pembelajaran matematika dengan pendekatan realistik sebagai berikut:

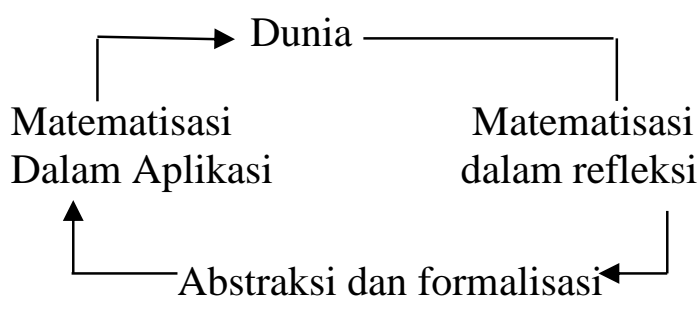

Gambar 2.3 Matematisasi konseptual

Gambar di atas menunjukkan bahwa proses belajar berlangsung dari situasi nyata, secara intuisi siswa pertamatama memiliki konsep-konsep mate- matika melalui situasi dunia nyata, kemudian mengabstraksikannya ke bentuk matematika atau mengidentifikasi aspekaspek matematika yang terkandung di dalam situasi dunia nyata tersebut. Dengan adanya interaksi siswa, siswa dan guru, guru dan lingkungan serta kemampuan siswa memformalkan dan mengabstrakkan konsep-konsep matematika yang akan melahirkan konsep matematika siswa, kemudian siswa dapat mengaplikasikannya dalam masalah serta situasi yang berbeda dan akhirnya dikembalikan pada dunia nyata.

\section{Pemanfataan Realitas dan Lingkung- an dalam Pembelajaran Matematika}

Dalam GBPP matematika SD dinyatakan bahwa pembelajaran matematika di mulai dari hal yang konkrit dilanjutkan ke hal yang abstrak, dari hal yang mudah ke hal yang sulit dan dari hal yang sederhana ke hal yang komplek. Untuk membantu pemahaman siswa dalam mata pelajaran matematika, guru hendaknya memilih sarana yang sesuai dengan bahan pengajaran dan menggunakan bahan sederhana atau mudah didapat di daerah. Karena itu perlu kiranya guru matematika terutama di SD mengusahakan alat peraga yang dapat membantu siswa memahami suatu konsep sampai pada penyelesaian soal. Menurut (Soedjadi, 2000:42) dijenjang Sekolah Dasar sifat konkrit objek matematika itu diusahakan lebih banyak atau lebih besar dari pada jenjang sekolah yang lebih tinggi. Semakin tinggi jenjang sekolahnya semakin besar sifat abstraknya. Jadi pembelajaran tetap diarahkan kepada pencapaian kemampuan berfikir abstrak siswa. Misalnya dalam menanamkan konsep persegi panjang dan persegi diawali dengan memperagakan bangun persegipanjang dan persegi yang dibuat dari kertas atau karton, diikuti dengan persegipanjang dan persegi yang dibentuk dari empat buah lidi. Baru 
kemudian meningkat pada gambarnya, selanjutnya bila perlu hanya dengan menyebutkan kata-katanya (nama konsep) seperti: "persegi panjang dan persegi". Dalam rangka mencapai tujuan di atas, sebaiknya implementasi kurikulum matematika di pendidikan dasar harus diperbaiki. Penekanan pembelajaran matematika di sekolah yang terletak pada hafalan logaritma harus diubah menuju penekanan pada pemahaman konseptual, penyusunan model, dan hubungan antara konsep serta penyelesaian masalah.

Dalam pembelajaran matematika sekolah selama ini realitas dan lingkungan itupun juga digunakan, yang terlihat dalam pemunculan soal cerita pada akhir pembahasan suatu topik atau sewaktu pemberian contoh sebagai aplikasi ma- teri. Pembelajaran matematika realistik tidak meniadakan fase penerapan matematika, namun menempatkan realitas dan lingkungan juga di fase awal pembelajaran untuk membangun konsepkonsep tertentu yang selanjutnya juga untuk mencapai simbolisasi atau perumusan umum. (Soedjadi, 2001:3) menyatakan bahwa dalam penerapan PMR yang berorientasi pada pemecahan masalah semenjak awal pembelajaran, perlu difikirkan masalah-masalah sederhana yang memungkinkan siswa dapat melakukan kegiatan yang mengarah kepada pembentukan konsep. Selanjutnya gambar berikut merupakan proses penerapan PMR, sekaligus menunjukkan pemanfaatan realitas dan lingkungan.

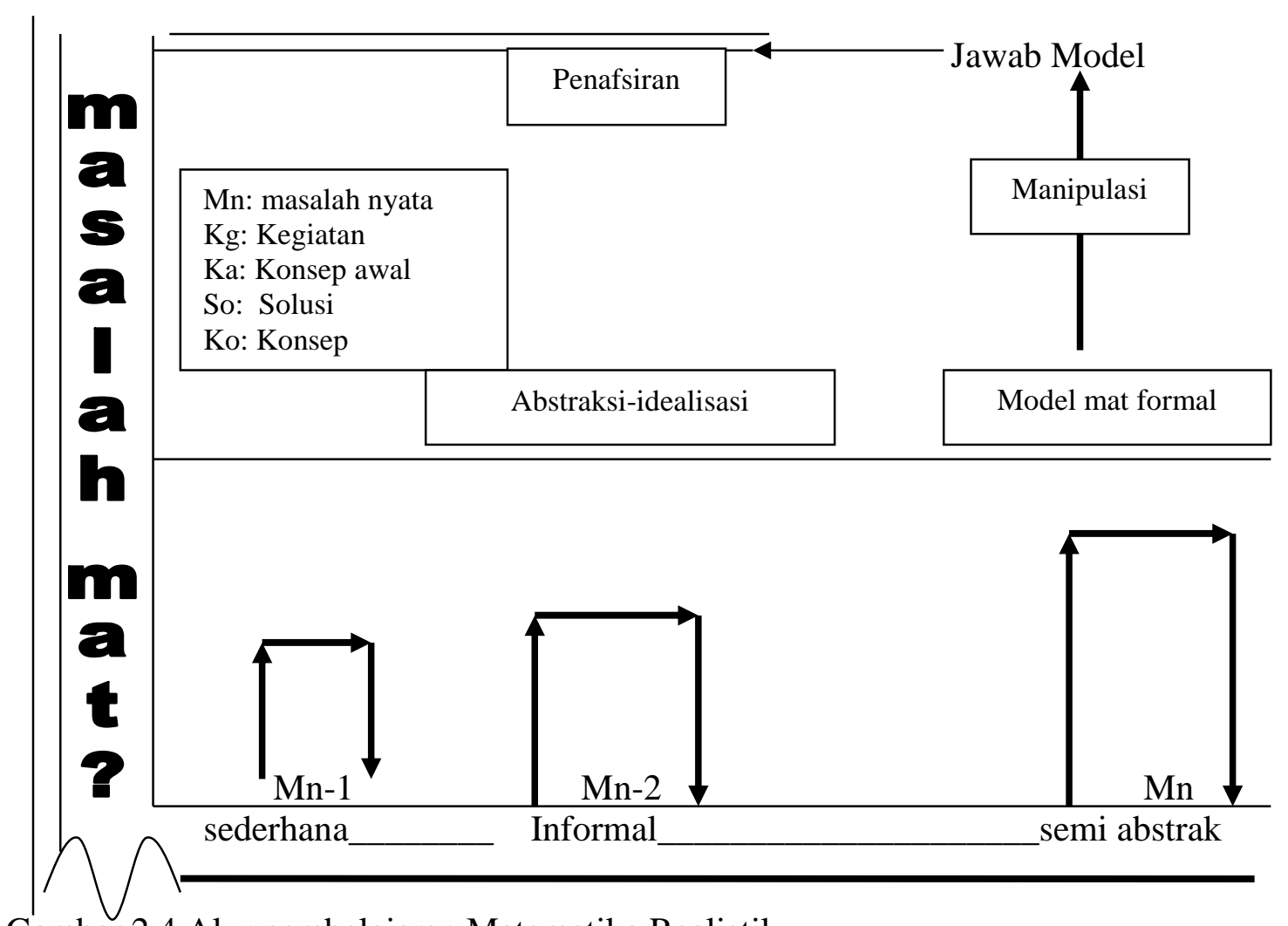

Gambar 2.4 Alur pembelajaran Matematika Realistik

Berdasarkan gambar di atas perlu dipikirkan masalah-masalah sederhana yang memungkinkan siswa dapat melakukan kegiatan mengarah kepada pembentukan konsep antara (misalnya kon- sep antara-1). Setelah konsep antara -1 diperoleh, mungkin diperlukan konsep antara-2 yang dibangun sejalan dengan konsep antara-1. Misalkan tujuan utama pembelajaran adalah untuk menentukan luas persegi panjang dan persegi. 
Konsep tersebut dapat dicapai melalui kegiatan membandingkan dua bangun datar tertentu. Selain lintas belajar di atas langkah-langkah PMR juga disusun berdasarkan prinsip dan karakteristik PMR.

\section{Prinsip dan Karakteristik PMR}

\section{Prinsip Pembelajaran Matematika Realistik}

Secara umum PMR mengkaji matematika tentang apa yang akan diajarkan serta mengapa matematika itu perlu diajarkan, bagaimana siswa belajar matematika serta bagaimana menilai kemajuan belajar siswa.

Soedjadi, 2002) mengemukakan 3 prinsip PMR, sebagai berikut:

a. Menemukan kembali (Guided Reinvention) dan matematisasi progresif.

Melalui topik-topik matematika yang disajikan, siswa harus diberikan kesempatan untuk mengalami proses yang sama dengan proses yang dilalui oleh para pakar matematika ketika menemukan konsep-konsep matematika. Hal ini dilakukan dengan cara memasukkan sejarah matematika, memberikan soal-soal kontekstual yang mempunyai berbagai kemungkinan solusi, dilanjutkan dengan matematisasi prosedur pemecahan yang sama, serta perancangan rute belajar sedemikian rupa sehingga siswa menemukan sendiri konsep-konsep yang akan dipelajari. b. Fenomena didaktik (didactical phenomenology)

Topik-topik matematika yang diajarkan berasal dari fenomena sehari-hari. Topikk-topik ini dipilih dengan dua pertimbangan: (1) aplikasinya, (2) kontribusinya untuk perkembangan matematika lanjut. Pembelajaran tidak lagi berorientasi pada guru, tetapi diubah dengan berorientasi pada siswa, bahkan mungkin sekali berorientasi pada masalah kontekstual yang dihadapi.

c. Model dibangun oleh siswa (self developed models)

Baik dalam matematisasi horizontal maupun matematisasi vertikal diharapkan model dibangun sendiri oleh siswa (mungkin ditempuh dengan model nyata atau model abstrak). Sewaktu memecahkan masalah kontekstual, pada awalnya siswa akan menggunakan model pemecahan yang informal (model of)

Setelah terjadi interaksi dan diskusi di kelas salah satu pemecahan yang dikemukakan oleh siswa akan berkembang menjadi model formal (model for). Selanjutnya pada gambar berikut (Gravemeijer dalam Fauzan, 2002: 43) membedakan antara proses pemodelan matematika yang ada dalam pendekatan strukturalistik dengan pemodelan yang ada dalam pendekatan realistik. 


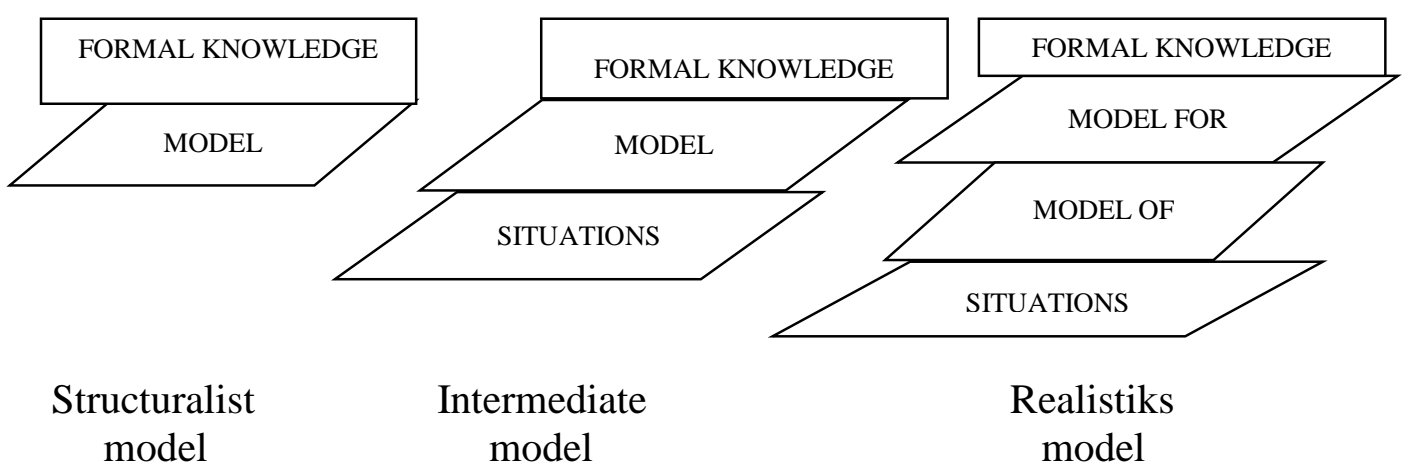

Gambar 2.5 Proses Pemodelan Matematika

\section{Karakteristik Pembelajaran Mate- matika Realistik}

Untuk memahami PMR lebih dalam, selanjutnya akan dibahas beberapa ka-rakteristik PMR sebagai berikut, yang mengacu pada prinsip PMR di atas.

\section{a. Menggunakan Konteks}

Menggunakan konteks yang nyata sebagai titik awal. Konteks adalah lingkungan keseharian siswa yang nyata. Ini dalam matematika tidak selalu diartikan konkrit, dapat juga diartikan dengan sesuatu yang dapat dipahami siswa lewat membayangkan.

b. Menggunakan Model

Model dapat beraneka ragam. Dapat model konkrit meningkat menjadi model abstrak. Dapat pula model dari situasi nyata (model of) dan model untuk arah abstrak (model for).

c. Menggunakan Kontribusi Siswa

Kontribusi yang besar pada proses belajar mengajar diharapkan datang dari siswa, artinya semua pikiran (konstruksi dan produksi) siswa diperhatikan. Kontribusi dapat berupa aneka jawab atau aneka cara dari siswa. d. Interaktif

Proses belajar mengajar akan berjalan dengan baik jika terjadi interaksi antara siswa-siswa, siswa-guru, gurulingkungan dan sebagainya.

e. Terintegrasi dengan topik lain (intertwining)

Topik-topik yang berbeda dalam matematika dapat diintegrasikan sehingga dapat memunculkan pemahaman tentang suatu konsep atau operasi secara serentak. Hal ini memungkinkan terjadinya penghematan waktu.

\section{Kelebihan dan Kelemahan Pembe- lajaran Matematika Realistik}

Menurut (Suwarsono,2001:5) terdapat beberapa kelebihan dari PMR, sebagai berikut:

a. Setiap pendekatan dalam proses pembelajaran pada dasarnya sama, Cuma setiap pendekatan PMR memberikan pengertian yang jelas dan operasional kepada siswa tentang keterkaitan antara matematika dengan kehidupan sehari-hari (kehidupan dunia nyata) dan tentang kegunaan matematika pada umumnya bagi manusia.

b. PMR memberikan pengertian yang jelas dan operasional kepada siswa bahwa maatematika adalah suatu bahan kajian yang dikonstruksi dan dikembangkan sendiri oleh siswa, tidak 
hanya oleh mereka yang disebut pakar dalam bidang tersebut.

c. PMR memberikan pengertian yang jelas dan operasional kepada siswa bahwa penyelesaian suatu masalah atau soal tidak harus tunggal, dan tidak harus sama antara siswa yang satu dengan siswa yang lainnya. Setiap siswa dapat menggunakan cara mereka sendiri, asalkan siswa itu bersungguh-sungguh dalam mengerjakan soal atau masalah tersebut. Selanjutnya dengan membandingkan cara penyelesaian yang satu dengan yang lain, akan bisa diperoleh cara penyelesaian yang paling tepat, sesuai dengan tujuan proses penyelesaian soal tersebut.

d. PMR memberikan pengertian yang jelas dan operasional kepada siswa bahwa dalam mempelajari matematika, proses pembelajaran merupakan suatu yang utama, dan untuk mempelajari matematika orang harus menjalani proses itu dan berusaha untuk menemukan sendiri konsepkonsep matematika, dengan bantuan pihak lain yang lebih tahu (misalnya guru). Tanpa kemauan untuk menjalani sendiri proses tersebut, pembelajaran yang bermakna tidak akan terjadi.

Selain kelebihan di atas, menurut (Suwarsono, 2001:8) terdapat juga bebe-rapa kerumitan tersendiri alam upaya implementasi pembelajaran matematika realistik (PMR) di dalam kelas, diantara-nya sebagai berikut.

a. Pemahaman tentang PMR dan upaya mengimplementasikan PMR membutuhkan perubahan pandangan yang sangat mendasar mengenai hal yang tidak mudah untuk dipraktekkan, misalnya mengenai guru, siswa dan peranan soal kontekstual. Di dalam PMR siswa tidak lagi dipandang sebagai pihak yang mempelajari segala sesuatu yang sudah jadi, tetapi dipandang sebagai pihak yang aktif mengkonstruksi konsep-konsep matematika. Guru tidak lagi sebagai pengajar, tetapi lebih sebagai pendamping bagi siswa. Disamping itu peranan soal kontekstual tidak hanya dipandang sebagai wadah untuk menerapkan aplikasi dari matematika, tetapi justru dijadikan sebagai titik pangkal untuk mengkonstruksi konsep-konsep matematika itu sendiri.

b. Pencarian soal-soal kontekstual yang memenuhi syarat-syarat yang dituntut PMR tidak selalu mudah untuk setiap topik matematika yang perlu dipelajari siswa, terlebih lagi soal tersebut harus bisa di selesaikan dengan berbagai cara.

c. Upaya mendorong siswa agar bisa menemukan berbagai cara untuk menyelesaikan soal juga bukan merupakan hal yang mudah bagi guru.

d. Proses pengembangan berfikir siswa, melalui masalah kontekstual, proses matematisasi horizontal dan vertikal juga bukan merupakan sesuatu yang sederhana karena proses dan mekanisme berfikir siswa.

Walaupun PMR punya hambatan dalam mengimplementasikan dalam pembelajaran matematika, namun hambatan ini sifatnya sementara. Dalam mengatasi hambatan ini PMR butuh waktu yang relative lama untuk merubah kebiasaan pembelajaran yang berlangsung secara konvensional.

\section{Metodologi Penelitian}

Penelitian ini memakai metode deskriptif dengan melukiskan keadaan objek atau peristiwa yang menggambarkan beberapa hal yang berkaitan dengan pembelajaran matematika realistik, yaitu respon siswa terhadap pembelajaran, tingkat aktivitas siswa, aktivitas guru selama mengelola pembelajaran, dan 
ketuntasan hasil belajar siswa pada MI di kabupaten Jombang Jawa Timur serta dapat membedakan hasil belajar siswa yang mengikuti pembelajaran matematika realistik dengan hasil belajar siswa yang mengikuti pembelajaran konvensional.

Yang menjadi populasi dalam penelitian ini adalah semua siswa kelas IV MIN Darul 'Ulum yang terdiri dari dua kelas. Sedangkan sampel penelitian sama dengan populasi. Berdasarkan keterangan kepala sekolah, pembagian kelas IV berdasarkan nilai yang merata, artinya siswa yang memiliki nilai rendah, sedang, dan tinggi merata pada tiap kelas. Kedua kelas yang dijadikan populasi adalah kelas IV A dan IV B. Selanjutnya dipilih secara acak satu kelas untuk kelas eksperimen dan satu kelas untuk control. Berdasarkan pemilihan secara acak tersebut, terpilih kelas IV A sebagai kelas eksperimen yang diajarkan dengan menggunakan pembelajaran matematika realistik. Sedangkan kelas IV B sebagai kelas kontrol diajarkan dengan menggunakan pembelajaran konvensional. Siswa kelas IV A berjumlah 31 orang dan kelas IV B berjumlah 35 orang.

\section{Analisis Deskriptif Hasil Penelitian}

Analisis deskriptif dilakukan untuk mendeskripsikan beberapa hal yang berkaitan pembelajaran matematika realistik pada materi luas, yang meliputi: hasil belajar siswa, aktivitas siswa, dan respon siswa terhadap pembelajaran matematika realistik.

\section{Respon Siswa}

Deskripsi data respon siswa yang didasarkan pada hasil angket yang ditulis siswa dapat dilihat pada tabel berikut,

Respon siswa terhadap komponen kegiatan pembelajaran

\begin{tabular}{|c|c|c|}
\hline Komponen & Baru & Tidak Baru \\
\hline & $(\%)$ & $(\%)$ \\
\hline Materi Pelajaran & 90,32 & 9,68 \\
\hline LKS & 96,77 & 3,23 \\
\hline Suasana Belajar & 87,10 & 12,90 \\
\hline Tugas Mandiri & 64,52 & 35,48 \\
\hline Cara Guru engajar & 93,55 & 6,45 \\
\hline
\end{tabular}

Minat Siswa untuk mengikuti pembelajaran matematika realistik

\begin{tabular}{|l|c|c|}
\hline \multicolumn{1}{|c|}{ Komponen } & Berminat & $\begin{array}{c}\text { Tidak } \\
\text { Berminat }\end{array}$ \\
\hline $\begin{array}{l}\text { Apakah kamu } \\
\text { berminat mengikuti } \\
\text { kegiatan belajar } \\
\text { selanjutnya seperti } \\
\text { yang telah kamu } \\
\text { ikuti sekarang? }\end{array}$ & 90,32 & $(\%)$ \\
\hline
\end{tabular}

Berdasarkan data tabel di atas diperoleh bahwa respon siswa untuk setiap indicator rata-rata di atas $80 \%$, sehingga berdasarkan kriteria dapat disimpulkan bahwa respon siswa terhadap komponen dan kegiatan pembelajaran positif.

\section{Aktivitas Siswa selama Kegiatan Pem- belajaran}

Menurut (Soedjadi, 2000:202) untuk memperoleh kadar siswa aktif belajar yang tinggi, sebelumnya siswa harus mempunyai sikap positif terhadap pembelajaran matematika. Apabila siswa mempunyai sikap positif terhadap pembelajaran matematika maka siswa akan termotivasi dan aktif dalam belajar. Berdasarkan hasil penelitian tentang aktivitas siswa menunjukkan bahwa secara keseluruhan pembelajaran matematika realistik mengaktifkan siswa. Hal ini menunjukkan bahwa pembelajaran matematika realistik dapat mengurangi dominasi guru dalam proses pembelajaran. Siswa mempunyai banyak kesempatan untuk menyelesaikan masalah atau menemukan jawaban dan cara untuk menyelesaikan masalah, berdiskusi atau bertanya antar siswa, dan berdiskusi atau bertanya antar siswa dan guru. 


\section{Aktivitas Guru selama mengelola Pembelajaran}

Sulitnya siswa memahami materi bisa jadi disebabkan oleh cara guru menyampaikan materi pelajaran. Guru sebagai penyelenggara pendidikan harus memikirkan pendekatan yang tepat agar interaksi terjadi secara optimal dan siswa dapat memahami materi terbaik.

Alam prinsip dan standar matematika sekolah NCTM (2000) ditegaskan bahwa untuk mendukung agar pembelajaran efektif, guru harus membangun komunitas di kelas sehingga para siswa merasa bebas untuk mengekspresikan pemikirannya. Menurut Suradi (2001:1) pembelajaran geometri di SD dan sekolah menengah cenderung beorientasi pada guru dan target materi, yang berdampak pembelajaran sering di interpretasikan sebagai aktivitas utama guru, jarang guru dalam pembelajarannya dimulai dengan penyelidikan masalah nyata geometri kemudian diarahkan pada penemuan konsep geometri.

Berdasarkan pengamatan tentang aktivitas guru selama mengelola pembelajaran, dapat disimpulkan bahwa aktivitas guru dalam mengelola pembelajaran efektif, walaupun indikator -6 yakni guru masih belum bisa menghilangkan sikap otoriternya dalam mengelola pembelajaran selama ini. Namun hal ini wajar terjadi karena dalam mengimplementasikan PMR tentu tidak bisa dalam waktu yang singkat dan dengan materi yang terbatas.

\section{Hasil Belajar Siswa}

Berdasarkan hasil respon siswa yang positif terhadap PMR, siswa menjadi tertarik dalam belajar matematika demikian sehingga siswa aktif pada kegiatan pembelajaran. Hal ini tentu akan berdampak pada hasil belajar siswa. Deskripsi hasil analisis penelitian menunjukkan bahwa persentase ketuntasan belajar siswa pada kelas eksperimen $80,65 \%$, sedangkan untuk kelas kontrol sebesar 34,29\% pada pokok bahasan yang sama. Sehingga secara klasikal, sesuai dengan kriteria pada bab III, hasil belajar siswa kelas eksperimen tidak tuntas. Ini kemungkinan disebabkan oleh beberapa hal, diantaranya adalah sebagai berikut. (1) PMR merupakan hal yang baru baik bagi guru maupun siswa, jadi tidak bisa dilaksanakan di kelas hanya dengan empat kali pertemuan karena perlu waktu untuk menyesuaikan diri. (2) untuk memahami satu materi pelajaran butuh waktu yang cukup lama, sehingga kalau kurikulum yang digunakan seperti yang berlaku sekarang ini dikhawatirkan tidak dapat menyelesaikan bahan ajar. (3) Dalam belajar berkelompok tidak semua siswa bisa aktif, siswa yang pasif hanya sebagai penonton. (4) Perangkat pembelajaran dan instrument penelitian yang disusun sulit dipahami siswa, karena masih banyak siswa yang tidak mengerti makna kata pendapat dan kesimpulan.

Walaupun hasil belajar kelas eksperimen tidak tuntas, namun dari persentase ketuntasan tersebut terlihat bahwa hasil belajar kelas eksperimen lebih baik dari hasil belajar kels control. Hal ini terlihat dari peningkatan skor dari pretest ke posttest, rentang skor tertinggi dan skor terendah, dan dari persentase ketuntasan secara klasikal pada kedua kelas tersebut.

\section{PENUTUP}

Berdasarkan analisis data penelitian tentang pembelajaran matematika Realistik pada materi luas, diperoleh beberapa kesimpulan sebagai berikut.

1. PMR efektif mengajarkan materi luas di kelas IV MI, karena semua syarat keefektifan dipenuhi, yaitu ketuntasan hasil belajar siswa secara klasikal tuntas, respon siswa terhadap pembelajaran matematika realistik positif 
dan pembelajaran matematika realistik efektif mengaktifkan siswa dan mengaktifkan guru dalam mengelola pembelajaran.

2. Hasil belajar siswa yang mengikuti pembelajaran matematika realistik

\section{DAFTAR RUJUKAN}

Brunning, R.G. dkk (2005). Cognitive Psychology and Instruction. New Jersey: Prentice-Hall.

Dahar, Ratna, W. (1988) Teori-teori belajar. Jakarta: Airlangga

Fauzan, A. (2002) Applying Realistics Mathematics Education (RME) in Teaching Geometry in Indonesian Primary. Thesis University of Twente, Enschede

Gravemeijer, K.P.E (1999). Developing Realistics Mathemetics Education. Freudenthal Institute. Ultrecht

Heuvel-Panhuizen, M. Van den (2000). Assessment and Realistics Matheatics Education. The Netherlands, Ultrecht: Freudenthal Institute

Hudojo, Herman (1988). Mengajar Beajar Matematika. P2LPTK. Dirjen Dikti. Jakarta

De Lange, Jan. (1999). Using and Applying Mathematics in Eduations. In A.J Bishop. Et. Al. Eds), nternational Handbook of Matheatics Education. 49-97. The Netherland: Kluwer Academic Publisher.

Marpaung (2001). Prospek RME untuk Pembelajaran Matematika di Inonesia. Makalah seminar nasional di Jurusan Matematika FMIPA UNESA: 24 Februari 2001.

National Council of Teacher of Mathematics. (2000a). Principles lebih baik dibandingkan hasil belajar siswa yang mengikuti pembelajaran matematika konvensional pada materi luas.

and Standards for School Mathematics. NCTM: Reston VA

Slavin, R. E (1994). Educational Psychology Theory and Practice. Boston: Allyn and Bacon

Soedjadi, R. (2000). Kiat Pendidikan Matematika di Indonesia: Konstaansi keadaan Masa Mini Menuju Harapan Masa Depan. Jakarta. Dirjen Dikti: Depdiknas

(2001a). Pemanfaatan Realitas dan Lingkungan dalam Pembelaja-n Matematika. Makalah seminar nasional di Jurusan Matematika FMIPA UNESA: 24 Februari 2001.

Suradi. (2001). Pembelajaran Berfikir Tingkat Tinggi Matematika tingkat $S D$. Junal Matematika dan Pemelajarannya: UNM

Suwarsono, St. (2001) Beberapa Perasalahan yang terkait dengan Upaya Implementasi Pendidikan Matematika Realistik di Indonesia. Makalah seminar nasional di Univ. Sanata Dharma Yokyakarta: 14-15 November 2001.

Treffers, A. (1999). Realistics Matheatics Education in the Netherlands 1980-1990 in Leen Streefland (Ed), Realistics Mathematics Edu-ation in Primary Schools. Ultrecht 
Indeks

guru, $73,151,154,155,157,158,159$, 160,161

Pembelajaran, 73, 151, 153, 154, 155, $157,160,161,90$

Luas, 73

Matematika, 73, 151, 153, 154, 155, $157,161,90$

Realistik, 73, 151, 153, 154, 155, 157, 161,90

Siswa, 73, 151, 152, 157, 159, 160 